\title{
Risk factors for deep vein thrombosis of lower extremities in Sudanese women
}

This article was published in the following Dove Press journal: Vascular Health and Risk Management

\section{Nadir Ahmed Ibrahim ${ }^{1,2}$ Fathelrahman M Hassan ${ }^{3}$ Mahmoud Mohamed Elgari Sana Eltahir Abdalla ${ }^{4}$}

'Department of Hematology and Immunohematology, College of Medical Laboratory Science, Sudan University of Science and Technology, Khartoum, Sudan; ${ }^{2}$ Department of Clinical Laboratory Sciences, Faculty of Applied Medical Sciences, Taibah University, Medina, Saudi Arabia; ${ }^{3}$ Department of Clinical Laboratory Science, College of Applied Medical Science, Imam Abdulrahman Bin Faisal University, Dammam, Saudi Arabia; ${ }^{4}$ Neelain Medical Research Centre, Al Neelain University, Khartoum, Sudan

Correspondence: Nadir Ahmed Ibrahim Department of Clinical Laboratory Sciences, Faculty of Applied Medical Sciences, Taibah University, Medina 4I4II, Saudi Arabia

Tel +96650l 486 I4I

Email nadir.ibrahim@outlook.com
Aim: In this study, we aimed to analyze the genetic and acquired risk factors for deep vein thrombosis (DVT) of the lower extremities among Sudanese women.

Methods: A total of 136 women were enrolled in the study, including 75 DVT patients and 61 healthy controls. Demographic and clinical data were collected using a specific questionnaire. Citrated blood samples of patients and controls were used for coagulation assays, and DNAs isolated from EDTAblood samples were used for the detection of Factor V Leiden and prothrombin G20210A mutations using multiplex polymerase chain reaction-restriction fragment length polymorphism analysis.

Results: Both gene mutations were found to be absent from all 136 subjects, and therefore did not account for the incidence of DVT in Sudanese women. Of the 75 DVTs, 70 (93.3\%) were localized in the left leg and $5(6.7 \%)$ in the right leg. Additionally, $84 \%$ of the DVTs were proximal and $16 \%$ were distal. Among the 75 patients, $22(29.33 \%)$ were postpartum, 7 $(9.33 \%)$ were pregnant, and $46(61.33 \%)$ were nonpregnant. Levels of prothrombin fragment $1+2$, prothrombin time, activated partial thromboplastin time, and D-dimer were significantly higher in DVT patients than in healthy controls $(P<0.0001)$.

Conclusion: Risk factors that most significantly affected patients in the $18-45$ years age group were pregnancy and oral contraceptive usage, whereas those that most significantly affected patients in the 66-90 years age group were immobility, heart disease, and history of DVT.

Keywords: pregnancy, oral contraceptive, DVT, Factor V (G1691A), prothrombin (G20210A), PCR-RFLP

\section{Introduction}

Deep vein thrombosis (DVT) occurs at an incidence ranging from $\sim 45$ to 117 in 100,000 adults per year. ${ }^{1}$ African Americans have higher rates of DVT than Caucasians. ${ }^{2,3}$ The prevalence of DVT in Africans varied between 380 and 448 per 100,000 births per year in pregnant and postpartum women, and between $2.4 \%$ and $9.6 \%$ in postoperative patients. ${ }^{4}$ DVT is a major cause of morbidity and mortality in older adults and one of the leading causes of maternal mortality in the western world. ${ }^{5}$ Venous thrombosis is a reproductive health risk for women. During pregnancy, the risk of venous thrombosis increases by up to 5-fold, and the risk further increases by 60 -fold postpartum. ${ }^{6}$ Furthermore, a large number of women worldwide are at a high risk of developing venous thrombosis because of the use of oral contraceptives or hormone replacement therapy (HRT). Moreover, women undergoing infertility treatment may be exposed to circumstances related with an increased risk of venous thrombosis. ${ }^{7}$ DVT is uncommon among patients younger than 40 years of age, and more common in women than in men amid reproductive 
age ${ }^{8}$ which supports the role of hormonal contraceptives and pregnancy in developing DVT during this period of life. ${ }^{9}$ The incidence of venous thrombosis is $\sim 1$ in 1000 pregnancies. ${ }^{10}$ Additionally, pregnant women are 6- to 10-fold more likely to develop DVT than nonpregnant women of the same age. ${ }^{11,12}$ Among pregnant women, the frequency of thrombosis is similar in each of the three trimesters and is increased during the postpartum period. ${ }^{13}$

Thrombophilia increases the risk of pregnancy- and oral contraceptive-associated venous thrombosis, especially in women with combined or homozygous defects. ${ }^{14}$ Factor V Leiden and prothrombin G20210A gene mutations are the most common forms of heritable thrombophilia. Both these mutations have a distinctive worldwide distribution; both mutations are the most prevalent among Caucasians and Middle Easterners, and have a moderate to rare prevalence among other populations, including Africans. Both mutations cause venous thrombosis with high mortality and morbidity. ${ }^{2,15,16}$ Factor V Leiden mutation renders Factor Va resistant to cleavage by activated protein $\mathrm{C}$ (APC), which results in increased thrombin generation and higher levels of prothrombin fragment $1+2 .{ }^{17-19}$ Mutant proteins confer a 5- to 10-fold greater risk of developing DVT in heterozygous individuals and a 50- to 100-fold higher risk in homozygotes compared with normal individuals. ${ }^{20}$ The second most common genetic risk factor for hereditary thrombophilia is the prothrombin gene mutation. Substitution of $\mathrm{G}$ to $\mathrm{A}$ at nucleotide at position 20,210 of the prothrombin gene leads to an increased prothrombin production. ${ }^{21}$ This defect is associated with a 3-fold greater risk of venous thrombosis. ${ }^{22}$ The prevalence of the G20210A prothrombin variant is between $1 \%$ and $4 \%$, and it appears to be highly rare in African individuals. ${ }^{23}$

In addition to genetic risk factors, there are several acquired risk factors for DVT, which are mostly identified in young and middle-aged women; these include prolonged immobility, surgery, malignant diseases, heart disease, pregnancy, HRT, and oral contraceptives..$^{7,24-26}$ In this study, we focused on identifying the acquired and genetic risk factors for DVT in Sudanese women and the interaction between them. We investigated risk factors for DVT in nonpregnant, pregnant, and postpartum women. Knowledge of these risk factors will enhance our understanding of the factors that increase the risk of developing DVT, which would further help medical practitioners to determine the optimal time and method of thromboprophylaxis and other treatments.

\section{Materials and methods}

\section{Study group}

This case control study was conducted from July 2014 to July 2017 in Khartoum State, the capital of Sudan. A total of 136 Sudanese women, including 75 female patients with confirmed DVT diagnosis using duplex ultrasound and 61 nonpregnant healthy females (controls), were recruited for this study. The control subjects had no history of venous thromboembolism or coagulation disorders. Demographic information and clinical data were collected from all subjects using a standardized questionnaire (Figure 1). EDTA-blood and citrated blood samples were collected for each individual for DNA extraction and coagulation tests, respectively.

\section{DNA extraction}

Total genomic DNA was extracted from peripheral blood using a G-spin DNA Extraction Kit (iNtRON Biotechnology Inc, Jungwon-gu, South Korea) according to the manufacturer's instructions.

\section{Coagulation assays}

Coagulation tests including prothrombin time (PT) and activated partial thromboplastin time (APTT) were performed using a STart 4 Hemostasis Analyzer (Diagnostica Stago, France). Fibrinogen assays and D-dimer tests were performed using Multifibren $U$ and Innovance D-dimer reagents, respectively, with a BCS XP System (Siemens Healthcare GmbH, Erlangen, Germany). The APC resistance test was performed using STA-STACLOT (Diagnostica Stago). Sandwich enzyme-linked immunosorbent assay (ELISA) was performed for the quantitative detection of prothrombin fragment 1+2 using Human Prothrombin Fragment 1+2 ELISA Kit (Abbexa, Cambridge, UK).

\section{Primer-engineered multiplex polymerase chain reaction (PCR)-restriction fragment length polymorphism (RFLP) detection of Factor $V$ Leiden and prothrombin G20210A}

Simultaneous detection methods were used for Factor V Leiden and prothrombin G20210A mutations in which the HindIII digested amplification products were analyzed via agarose gel electrophoresis in a single gel lane and visualized by ethidium bromide staining. ${ }^{27}$ A 241-bp region of exon 10 of Factor $V$ gene, and 506 bp of the $3^{\prime}$ untranslated region of the prothrombin gene was PCR amplified using gene-specific primers as previously described, ${ }^{27}$ with some modifications. Briefly, each $25 \mu \mathrm{L}$ PCR reaction comprised $100 \mathrm{ng}$ genomic DNA, $12.5 \mu \mathrm{L}$ of $2 \mathrm{X}$ GoTaq Green Master Mix (Promega Corporation, Fitchburg, WI, USA), 0.6 $\mu \mathrm{L}$ of $10 \mathrm{pM}$ each of the forward primers, $0.4 \mu \mathrm{L}$ of 10 
Figure I Questionnaire designed to collect demographics: age, sex, ethnicity (tribe), and patient and family history.

\begin{tabular}{|c|c|c|c|c|c|c|}
\hline 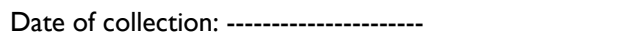 & \multicolumn{6}{|c|}{ Research ID number: ----------- } \\
\hline Name of patient: ------------- & \multicolumn{6}{|c|}{ Age (in years) --- } \\
\hline Gender: & Male & $\square$ & $\mathrm{Fe}$ & emale & & $\square$ \\
\hline 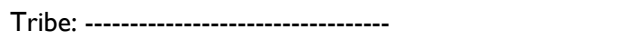 & \multicolumn{5}{|c|}{ 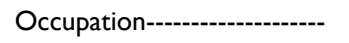 } & \\
\hline Initial diagnosis: & \multicolumn{2}{|c|}{ Proximal } & $\square$ & \multicolumn{2}{|c|}{ Distal } & $\square$ \\
\hline Affected leg: & \multicolumn{2}{|c|}{ Right } & $\square$ & \multicolumn{2}{|c|}{ Left } & $\square$ \\
\hline Duration of illness: & $---\cdot$ & 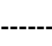 & ------ & ------ & --- & ---- \\
\hline Pregnant: & Yes & $\square$ & No & & $\square$ & \\
\hline Postpartum: & Yes & $\square$ & No & & $\square$ & \\
\hline Under surgery: & Yes & $\square$ & No & & $\square$ & \\
\hline Immobility status: & Yes & $\square$ & No & & $\square$ & \\
\hline Bone fracture: & Yes & $\square$ & No & & $\square$ & \\
\hline Clotting disorder: & Yes & $\square$ & No & & $\square$ & \\
\hline Hormone therapy: & Yes & $\square$ & No & & $\square$ & \\
\hline Cancer: & Yes & $\square$ & No & & $\square$ & \\
\hline Oral contraceptive: & Yes & $\square$ & No & & $\square$ & \\
\hline Cigarette smoking: & Yes & $\square$ & No & & $\square$ & \\
\hline Renal failure: & Yes & $\square$ & No & & $\square$ & \\
\hline Heart disease: & Yes & $\square$ & No & & $\square$ & \\
\hline On warfarin anticoagulant: & Yes & $\square$ & No & & $\square$ & \\
\hline On heparin anticoagulant: & Yes & $\square$ & No & & $\square$ & \\
\hline Family history of thromboembolism: & Yes & $\square$ & No & & $\square$ & \\
\hline How many members of your family have thrombosis? & ............. & $\ldots$ & & & & \\
\hline
\end{tabular}

pM each of the reverse primers, and $6.5 \mu \mathrm{L}$ of not diethyl pyrocarbonate-treated nuclease-free water (Thermo Fisher Scientific, Waltham, MA, USA). The PCR was performed as follows: initial denaturation at $95^{\circ} \mathrm{C}$ for 10 minutes, followed by 40 cycles of denaturation at $94^{\circ} \mathrm{C}$ for 1 minute, annealing at $55^{\circ} \mathrm{C}$ for 1 minute, and extension at $72^{\circ} \mathrm{C}$ for 1 minute, and a final extension at $72^{\circ} \mathrm{C}$ for 5 minutes. Subsequently, $10 \mu \mathrm{L}$ of each PCR product was digested with $1.0 \mu \mathrm{L}$ of $10 \mathrm{U}$ HindIII (Thermo Fisher Scientific) with $2 \mu \mathrm{L}$ of $10 \mathrm{X}$ enzyme buffer and $18 \mu \mathrm{L}$ of nuclease-free water at $37^{\circ} \mathrm{C}$ for at least 3 hours. The digestion products were separated by gel electrophoresis on a $\%$ agarose gel (Sigma-Aldrich Co, St Louis, MO, USA) and stained with ethidium bromide. Undigested products resulted in two products of 241 and 506 bp, representing Factor $\mathrm{V}$ and prothrombin amplicons, respectively. The digestion of wild-type alleles resulted in fragments of sizes 241 bp for Factor V and 407 bp +99 bp for prothrombin. The digestion of Factor V Leiden homozygous mutants produced 209 and 32 bp fragments, whereas digestion of prothrombin G20210A homozygous mutants produced three fragments of sizes 384,99 , and $23 \mathrm{bp}$. The digestion of heterozygous individuals carrying Factor $\mathrm{V}$ Leiden mutation yielded fragments of sizes 241, 209, and 32 bp, whereas heterozygous prothrombin G20210A mutants yielded fragments of 407, 384, and $99 \mathrm{bp}$.

\section{Statistical analysis}

Statistical Package for Social Sciences (SPSS Statistics version 20; IBM Corporation, Armonk, NY, USA) was used for statistical analysis. Results were expressed as mean \pm SD. Continuous variables were analyzed by Student's $t$-test.

\section{Ethical approval}

This research related to human use complied with all the relevant national regulations, institutional policies, and tenets of the Helsinki Declaration, and has been approved by the Research Ethical Committee of Sudan University of Science and Technology.

Written informed consent was obtained from all individual participants included in the study.

\section{Results}

A total of 136 Sudanese women, including 75 DVT patients and 61 normal controls, were evaluated. There was a significant difference between the mean age of DVT patients (40.75 \pm 16.630 years) and controls $(31.31 \pm 8.698$ years) 
( $P=0.000$ ). Among the 75 patients, $29.33 \%$ were postpartum $(\mathrm{n}=22), 9.33 \%$ were pregnant $(\mathrm{n}=7)$, and $61.33 \%$ were nonpregnant $(\mathrm{n}=46)$. Of the 7 pregnant women, the number of women in their first, second, and third trimesters were 3 (42.9\%), $2(28.6 \%)$, and $2(28.6 \%)$, respectively. Of the 75 DVTs, $93.3 \%$ were present in the left leg and $6.7 \%$ in the right leg; moreover, $84 \%$ were proximal and $16 \%$ were distal (Table 1). Among pregnant women, DVTs were always located on the proximal end of the left leg. Among postpartum women, however, DVTs were present in the right leg in 4 women and in the left leg in 8 women; all cases of DVTs were proximal among postpartum women.

We also compared the results of blood coagulation assays between DVT patients and controls. Data showed that levels of prothrombin fragment $1+2$, PT, APTT, and D-dimer were significantly higher in DVT patients than in healthy controls $(P=0.000)$ (Table 2). Table 3 categorizes the 75 DVT patients according to various risk factors. Additionally, we examined

Table I Demographics, clinical characteristics, and treatment patterns of the study group $(n=75)$

\begin{tabular}{ll}
\hline Characteristics & $(\mathbf{n}=\mathbf{7 5})$ \\
\hline Age (years) (mean \pm SD) & $40.75 \pm 16.630$ \\
Nonpregnant, $\mathrm{n}(\%)$ & $46.0(61.33)$ \\
Pregnant, $\mathrm{n}(\%)$ & $7.0(9.33)$ \\
Postpartum, $\mathrm{n}(\%)$ & $22.0(29.33)$ \\
Duration of illness/days (mean \pm SD) & $9.59 \pm 5.73 \mathrm{I}$ \\
Proximal DVT, $\mathrm{n}(\%)$ & $63.0(84.0)$ \\
Distal DVT, $\mathrm{n}(\%)$ & $12.0(16.0)$ \\
Right leg, $\mathrm{n}(\%)$ & $5(6.7)$ \\
Left leg, $\mathrm{n}(\%)$ & $70(93.3)$ \\
Anticoagulant therapy, $\mathrm{n}(\%)$ & \\
Heparin & $50(66.7)$ \\
Warfarin & $1(1.3)$ \\
Heparin and warfarin & $24(32.0)$ \\
\hline
\end{tabular}

Abbreviation: DVT, deep vein thrombosis.

Table 2 Comparison of coagulation assay results between DVT patients $(n=75)$ and healthy controls $(n=6 I)$

\begin{tabular}{llll}
\hline & Subject & Mean \pm SD & P-value \\
\hline Prothrombin time & Test & $23.23 \pm 10.36$ & $<0.000 \mathrm{I}$ \\
& Control & $1 \mathrm{I} .64 \pm 0.75$ & \\
Prothrombin fragment & Test & $12.64 \pm 1.3 \mathrm{I}$ & $<0.000 \mathrm{I}$ \\
$\mathrm{I}+2$ & Control & $4.44 \pm 2.84$ & \\
D-dimer & Test & $0.66 \pm 0.2 \mathrm{I}$ & $<0.000 \mathrm{I}$ \\
& Control & $0.3 \mathrm{I} \pm 0.19$ & \\
Activated partial & Test & $40.55 \pm 14.82$ & $<0.000 \mathrm{I}$ \\
thromboplastin time & Control & $31.57 \pm 7.03$ & \\
Activated protein C & Test & $2.69 \pm 0.32$ & 0.508 \\
resistance & Control & $2.73 \pm 0.39$ & \\
Fibrinogen & Test & $2.96 \pm 0.47$ & 0.878 \\
& Control & $2.94 \pm 0.54$ & \\
\hline
\end{tabular}

Abbreviation: DVT, deep vein thrombosis.
Table 3 Environmental risk factors among DVT patients $(n=75)$

\begin{tabular}{lll}
\hline & $\mathbf{n}$ & $\%$ \\
\hline Age $\geq 40$ years & 35 & 46.7 \\
Oral contraceptives & 25 & 33.3 \\
Postpartum & 22 & 29.33 \\
Under surgery & 18 & 24.0 \\
Cardiovascular disease & 12 & 16.0 \\
Previous history of DVT & 8 & 10.7 \\
Pregnancy & 7 & 9.3 \\
Immobility status & 7 & 9.3 \\
Obesity & 6 & 8.0 \\
Renal failure & 2 & 2.7 \\
Bone fracture & 1 & 1.3 \\
Hormone therapy & 0 & 0.0 \\
Cigarette smoking & 0 & 0.0 \\
Cancer & 0 & 0.0 \\
No risk factors & 12 & 16.0 \\
I risk factor & 32 & 42.7 \\
2 risk factors & 26 & 34.7 \\
$\geq 3$ risk factors & 5 & 6.7 \\
\hline
\end{tabular}

Abbreviation: DVT, deep vein thrombosis.

the risk factors for DVT according to the age of patients (Table 4). The 75 DVT patients were divided into three age groups (18-45, 46-65, and 66-90 years) and assessed for the environmental risk factors for DVT. Among the younger patients (18-45 years), postpartum and oral contraceptives usage were the most significant risk factors for DVT. By contrast, immobility status, heart disease, and history of DVT were the most significant risk factors affecting older patients (66-90 years). Notably, Factor V Leiden and prothrombin G20210A mutations were absent from all 136 individuals (Figure 2). As a result, no correlation was observed between DVT and the genetic risk factors for DVT among Sudanese women.

\section{Discussion}

Although the awareness of DVT as an important health issue is growing, ${ }^{28,29}$ our understanding of the DVT risk factors remains limited. Blood in women is more likely to coagulate than that in men because this property of blood in women protects against excessive bleeding during pregnancy, miscarriage, and childbirth. Both genetic and acquired risk factors can further increase the risk of thrombosis. ${ }^{30}$ Knowledge of genetic and environmental risk factors is crucial for the effective application of diagnostic, prophylactic, and therapeutic interventions, especially among women in childbearing age who are at a higher risk of developing DVT.

In women of reproductive age, over half of all venous thrombotic events are related to pregnancy and puerperium. ${ }^{6,31}$ However, we found that $29.3 \%$ of DVT women were postpartum and $9.3 \%$ were pregnant, indicating that both 
Table 4 Risk factors in DVT patients according to age

\begin{tabular}{|c|c|c|c|c|c|}
\hline & & \multicolumn{4}{|c|}{ Age in groups } \\
\hline & & \multirow{2}{*}{$\frac{18-45 \text { years }}{n(\%)}$} & \multirow{2}{*}{$\frac{46-65 \text { years }}{n(\%)}$} & \multicolumn{2}{|c|}{$66-90$ years } \\
\hline & & & & n (\%) & $P$-value \\
\hline \multirow[t]{2}{*}{ Previous history of DVT } & Yes & $0(0.0)$ & I (8.3) & $7(77.8)$ & $<0.0001$ \\
\hline & No & $54(100.0)$ & II (9I.7) & $2(22.2)$ & \\
\hline \multirow[t]{2}{*}{ Obesity } & Yes & $5(9.3)$ & I (8.3) & $0(0.0)$ & 0.637 \\
\hline & No & $49(90.7)$ & II (9I.7) & $9(100.0)$ & \\
\hline Hormonal therapy & No & $54(100.0)$ & $12(100.0)$ & $9(100.0)$ & - \\
\hline \multirow[t]{2}{*}{ Pregnancy } & Yes & $5(9.3)$ & I (8.3) & $0(0.0)$ & 0.223 \\
\hline & No & $49(90.7)$ & II (9I.7) & $9(100.0)$ & \\
\hline \multirow[t]{2}{*}{ Postpartum } & Yes & $7(13.0)$ & $0(0.0)$ & $0(0.0)$ & 0.002 \\
\hline & No & $47(87.0)$ & $12(100.0)$ & $9(100.0)$ & \\
\hline \multirow[t]{2}{*}{ Oral contraceptives } & Yes & $19(35.2)$ & $2(16.7)$ & $0(0.0)$ & 0.059 \\
\hline & No & $35(64.8)$ & $10(83.3)$ & $9(100.0)$ & \\
\hline Cigarette smoking & No & $54(100.0)$ & $12(100.0)$ & $9(100.0)$ & - \\
\hline \multirow[t]{2}{*}{ Under surgery } & Yes & $14(25.9)$ & $2(16.7)$ & $2(22.2)$ & 0.787 \\
\hline & No & $40(74.1)$ & $10(83.3)$ & 7 (77.8) & \\
\hline \multirow[t]{2}{*}{ Bone fracture } & Yes & I (I.9) & $0(0.0)$ & $0(0.0)$ & 0.821 \\
\hline & No & $53(98.1)$ & $12(100.0)$ & $9(100.0)$ & \\
\hline \multirow[t]{2}{*}{ Immobility status } & Yes & $2(3.7)$ & $0(0.0)$ & $5(55.6)$ & $<0.000$ I \\
\hline & No & $52(96.3)$ & $12(100.0)$ & $4(44.4)$ & \\
\hline \multirow[t]{2}{*}{ Heart disease } & Yes & $2(3.7)$ & $3(25.0)$ & 7 (77.8) & $<0.0001$ \\
\hline & No & $52(96.3)$ & $9(75.0)$ & $2(22.2)$ & \\
\hline \multirow[t]{2}{*}{ Renal failure } & Yes & I (I.9) & I (8.3) & $0(0.0)$ & 0.393 \\
\hline & No & $53(98.1)$ & II (9I.7) & $9(100.0)$ & \\
\hline Cancer & No & $54(100.0)$ & $12(100.0)$ & $9(100.0)$ & - \\
\hline
\end{tabular}

Abbreviation: DVT, deep vein thrombosis.

periods were associated with high risk of venous thrombosis. These data are in agreement with previous studies reporting approximately two and five times as many postpartum as antepartum DVT events, respectively. ${ }^{6,32,33}$ Moreover, Gader et al previously reported that most of the DVT events among Sudanese women occurred in the postpartum period. ${ }^{34}$ Consistent with our findings, James et al have reported that the risk of DVT was higher in pregnant women in their first trimester than those in their second or third trimesters. Thus, if prophylaxis is indicated, it should be initiated early in gestation. ${ }^{35}$ However, DVT rates in the third trimester were higher according to a previous meta-analysis. ${ }^{36}$ Here, we observed that in most of the cases, DVTs occurred in the lower left extremity and were proximal. This was particularly true among pregnant women; DVTs in all pregnant women occurred on the proximal end of the left leg. These observations were in complete agreement with previous studies. ${ }^{34,36-38}$ However, why the left leg is the preferred site for DVTs is unknown. ${ }^{39}$
Fibrin-related markers, such as D-dimer, and prothrombin fragment $1+2$ are considered to be useful for the diagnosis of thrombosis. ${ }^{40}$ In this study, significant differences were observed between DVT patients and healthy controls in prothrombin fragment $1+2$, PT, APTT, and D-dimer levels.

The development of DVT involves the interaction of multiple modifiable and non-modifiable risk factors. ${ }^{41}$ The non-modifiable risks include Factor $\mathrm{V}$ Leiden and prothrombin G20210A mutations, which are the two most predominant DVT-associated mutations worldwide. ${ }^{23,42}$ Available data suggest that Factor V Leiden carriers are at a 5- to 16-fold greater risk of developing DVT during pregnancy and puerperium than women homozygous for the wild-type Factor V, and are at a 35- to 100-fold greater risk among carriers using oral contraceptives. ${ }^{14}$ The risk of pregnancyassociated venous thrombosis was 15 -fold higher in women with the prothrombin gene mutation than those with the wild-type prothrombin gene. Moreover, the combination of oral contraceptives with the prothrombin gene mutation has 


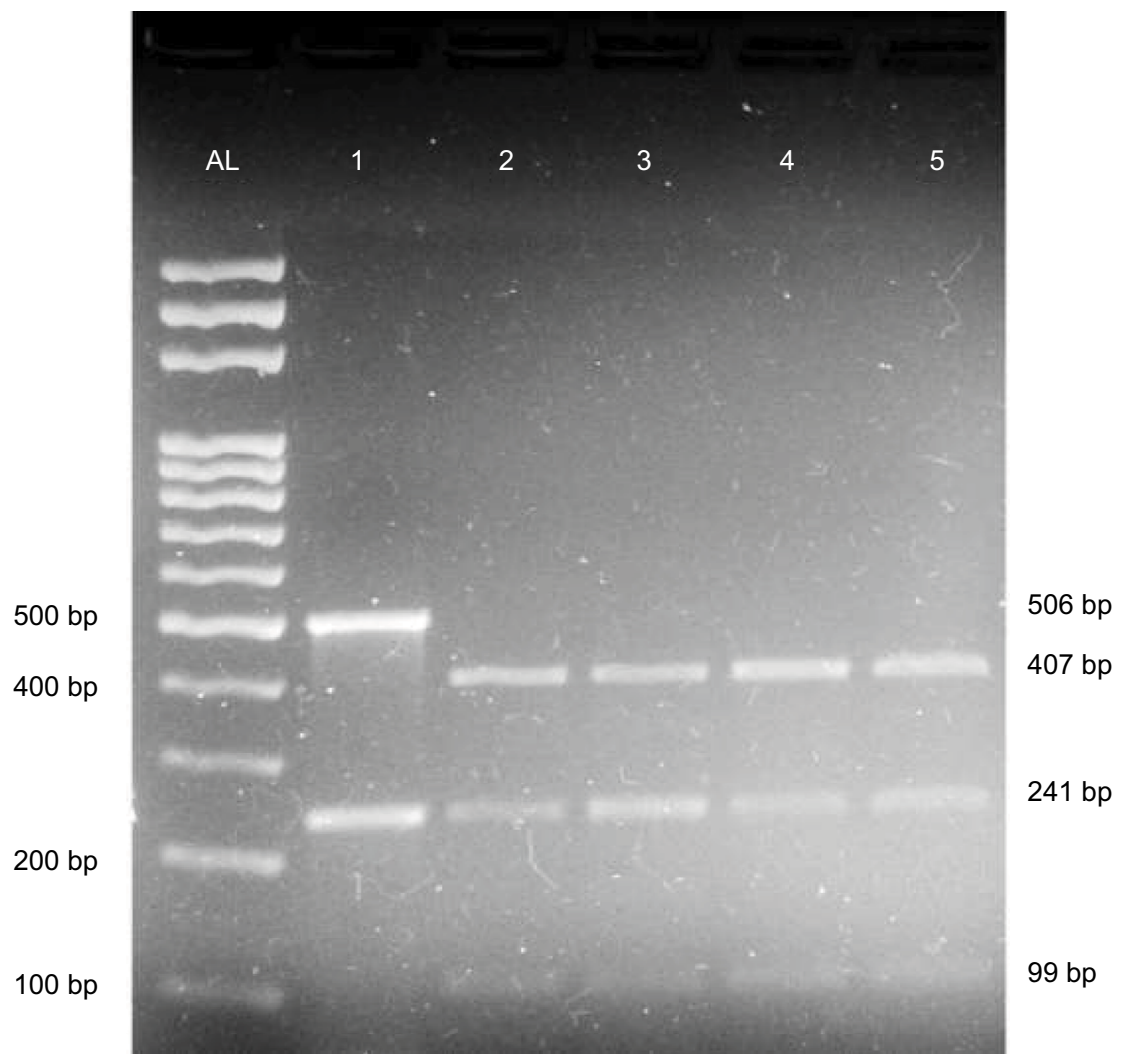

Figure 2 Multiplex PCR-RFLP for detecting Factor V Leiden and prothrombin G20210A mutations in DNA isolated from blood samples of Sudanese women. Photograph shows ethidium bromide-stained $2 \%$ agarose gel. AL denotes 100 bp DNA ladder. Lane I: undigested wild-type 506 bp (prothrombin) and 24I bp (Factor V). Lanes 2-5: digested wild-type amplicons 407 and 99 bp (prothrombin) and 24I bp (Factor V).

Abbreviations: PCR, polymerase chain reaction; RFLP, restriction fragment length polymorphism.

a multiplicative effect on the overall thrombotic risk, with the odds ratio ranging from 16 to 59 , as suggested previously. ${ }^{14}$ However, our study demonstrated a total absence of Factor V Leiden and prothrombin G20210A mutations among Sudanese women. Therefore, no association was observed between these mutations and DVT in our study population, which is in accordance with the results of other studies. ${ }^{28,43,44}$ By contrast, a very low prevalence of Factor $\mathrm{V}$ Leiden mutation has been shown among healthy individuals in Sudan..$^{29}$ Nonetheless, it is noteworthy that in Sudan, one of the economically struggling countries, it is a priority to adopt robust, cost-effective, and quick diagnostic tools for molecular analysis. The multiplex PCR-RFLP-based analysis used in this study for the simultaneous detection of both Factor V Leiden and prothrombin G20210A mutations was a stable and reproducible single-tube reaction requiring no special or expensive equipment and only a small amount of standard PCR reagents.

Venous thrombosis is commonly a disease of older adults. ${ }^{26}$ Our study revealed a significant difference between the mean age of DVT patients and healthy controls. Approximately $47 \%$ of the DVT patients were $>40$ years old. However, this also means that $53 \%$ of the DVT patients were $<40$ years of age. This was expected, as the incidence rates of DVT are slightly higher in women in their childbearing age. ${ }^{1}$ When DVT patients were divided into three groups according to age, we found that heart disease and history of venous thrombosis were the most predominant risk factors among elderly women, followed by immobility, which affected more than half of the elderly women. This was consistent with a previous study. ${ }^{45}$ Among younger patients, the risk factors most significantly related to DVT were postpartum and oral contraceptive usage. These findings were in accordance with previous reports. ${ }^{6,33,34,44}$

Since 1996, a large number of observational studies have consistently shown a significant (2- to 4-fold) increase in the relative risk of developing venous thromboembolism in HRT users compared with nonusers. ${ }^{14}$ Because none of the women involved in this study were undergoing HRT, its association with DVT in this study group was not investigated. 
In summary, Factor V Leiden and prothrombin G20210A mutations were not associated with DVT in Sudanese women examined in this study. Further investigations into other hereditary causes of DVT among Sudanese women are needed. Multiplex PCR-RFLP analysis is a highly efficient and cost-effective method, and therefore, it is ideal for laboratories with limited budget. Women who are in their reproductive age or postpartum period and those using oral contraceptives are at a higher risk of developing DVT than other women. Additionally, older women with a history of DVT, heart disease, or prolonged immobility are also at a high risk of developing DVT. Therefore, special care should be given to both these groups to avoid the development of DVT.

\section{Acknowledgments}

Special thanks to the research assistants at the Sudan University of Science and Technology research laboratory, medical staff at Omdurman Maternity Hospital, and the medical staff of Ibrahim Malik Teaching Hospital who helped us during conduction of this study. The authors would like to thank Enago (www.enago.com) for the English language review.

\section{Disclosure}

The authors report no conflicts of interest in this work.

\section{References}

1. Heit JA. Epidemiology of venous thromboembolism. Nat Rev Cardiol. 2015;12(8):464-474.

2. White RH. The epidemiology of venous thromboembolism. Circulation. 2003;107(23 Suppl 1):I4-I8.

3. Zakai NA, McClure LA, Judd SE, et al. Racial and regional differences in venous thromboembolism in the United States in 3 cohorts. Circulation. 2014;129(14):1502-1509.

4. Danwang C, Temgoua MN, Agbor VN, Tankeu AT, Noubiap JJ. Epidemiology of venous thromboembolism in Africa: a systematic review. J Thromb Haemost. 2017;15(9):1770-1781.

5. Virkus RA, Løkkegaard E, Lidegaard Ø, et al. Risk factors for venous thromboembolism in 1.3 million pregnancies: a nationwide prospective cohort. PLoS One. 2014;9(5):e96495.

6. Pomp ER, Lenselink AM, Rosendaal FR, Doggen CJM. Pregnancy, the postpartum period and prothrombotic defects: risk of venous thrombosis in the MEGA study. J Thromb Haemost. 2008;6(4):632-637.

7. Eichinger S, Evers JLH, Glasier A, et al. Venous thromboembolism in women: a specific reproductive health risk. Hum Reprod Update. 2013;19(5):471-482.

8. Silverstein MD, Heit JA, Mohr DN, Petterson TM, O'Fallon WM, Melton LJ 3rd. Trends in the incidence of deep vein thrombosis and pulmonary embolism: a 25-year population-based study. Arch Intern Med. 1998;158(6):585-593.

9. Bleker SM, Coppens M, Middeldorp S. Sex, thrombosis and inherited thrombophilia. Blood Rev. 2014;28(3):123-133.

10. McColl MD, Ramsay JE, Tait RC, et al. Risk factors for pregnancy associated venous thromboembolism. Thromb Haemost. 1997;78(4):1183-1188.

11. Eldor A. Thrombophilia, thrombosis and pregnancy. Thromb Haemost. 2001;85(1):104-111

12. Martinelli I. Risk factors in venous thromboembolism. Thromb Haemost. 2001;86(1):395-403.
13. Devis P, Knuttinen MG. Deep venous thrombosis in pregnancy: incidence, pathogenesis and endovascular management. Cardiovasc Diagn Ther. 2017;7(Suppl 3):S309-S319.

14. Kujovich JL. Hormones and pregnancy: thromboembolic risks for women. Br J Haematol. 2004;126(4):443-454.

15. Frutos PG. Mechanisms of thrombophilia. Thromb Haemost. 2007;98(3):485-487.

16. Naess IA, Christiansen SC, Romundstad P, Cannegieter SC, Rosendaal FR, Hammerstrøm J. Incidence and mortality of venous thrombosis: a population-based study. J Thromb Haemost. 2007;5(4):692-699.

17. Franco RF, Reitsma PH. Genetic risk factors of venous thrombosis. Hum Genet. 2001;109(4):369-384.

18. Robetorye RS, Rodgers GM. Update on selected inherited venous thrombotic disorders. Am J Hematol. 2001;68(4):256-268.

19. Simioni P, Scarano L, Gavasso S, et al. Prothrombin fragment $1+2$ and thrombin-antithrombin complex levels in patients with inherited APC resistance due to Factor V Leiden mutation. Br J Haematol. 1996;92(2):435-441.

20. Dahlback B. New molecular insights into the genetics of thrombophilia. Resistance to activated protein C caused by Arg506 to Gln mutation in factor $\mathrm{V}$ as a pathogenic risk factor for venous thrombosis. Thromb Haemost. 1995;74(1):139-148.

21. Poort SR, Rosendaal FR, Reitsma PH, Bertina RM. A common genetic variation in the $3^{\prime}$-untranslated region of the prothrombin gene is associated with elevated plasma prothrombin levels and an increase in venous thrombosis. Blood. 1996;88(10):3698-3703.

22. Evaluation of Genomic Applications in Practice and Prevention (EGAPP) Working Group. Recommendations from the EGAPP Working Group: routine testing for Factor V Leiden (R506Q) and prothrombin $(20210 \mathrm{G}>\mathrm{A})$ mutations in adults with a history of idiopathic venous thromboembolism and their adult family members. Genet Med. 2011;13(1):67-76.

23. Rosendaal FR, Doggen CJ, Zivelin A, et al. Geographic distribution of the $20210 \mathrm{G}$ to A prothrombin variant. Thromb Haemost. 1998;79(4):706-708.

24. Lippi G, Franchini M. Pathogenesis of venous thromboembolism: when the cup runneth over. Semin Thromb Hemost. 2008;34(8):747-761.

25. Binder B, Lackner HK, Salmhofer W, Hofmann-Wellenhof R. Risk factors for deep vein thrombosis in women aged 18 to 50: a retrospective analysis. Dermatol Surg. 2009;35(3):451-456.

26. Cushman M. Epidemiology and risk factors for venous thrombosis. Semin Hematol. 2007;44(2):62-69.

27. Huber S, McMaster KJ, Voelkerding KV. Analytical evaluation of primer engineered multiplex polymerase chain reaction-restriction fragment length polymorphism for detection of Factor $\mathrm{V}$ Leiden and prothrombin G20210A. J Mol Diagn. 2000;2(3):153-157.

28. Alfatih Aboalbasher Y, Abdel Rahim Mahmmoud M, Elwaleed Mohamed E, Ahmed A. The role of factor V Leiden 1691G>A and prothrombin gene $20210 \mathrm{G}>\mathrm{A}$ mutations in hypercoagulable state associated with venous thromboembolism among Sudanese patients. J Blood Disord Transfus. 2017;8:386.

29. Awad-Elkareem A, Elzaki SG, Khalid H, Abdallah MS, Adam I. A low rate of Factor V Leiden mutation among Sudanese women with deep venous thrombosis during pregnancy and puerperium. J Obstet Gynaecol. 2017;37(7):963-964.

30. James AH. Thrombosis in pregnancy and maternal outcomes. Birth Defects Res C Embryo Today. 2015;105(3):159-166.

31. Martinelli I, De Stefano V, Taioli E, Paciaroni K, Rossi E, Mannucci PM. Inherited thrombophilia and first venous thromboembolism during pregnancy and puerperium. Thromb Haemost. 2002;87(5):791-795.

32. Simpson EL, Lawrenson RA, Nightingale AL, Farmer RD. Venous thromboembolism in pregnancy and the puerperium: incidence and additional risk factors from a London perinatal database. BJOG. 2001;108(1):56-60.

33. Heit JA, Kobbervig CE, James AH, Petterson TM, Bailey KR, Melton LJ 3rd. Trends in the incidence of venous thromboembolism during pregnancy or postpartum: a 30-year population-based study. Ann Intern Med. 2005;143(10):697-706. 
34. Gader AA, Haggaz AED, Adam I. Epidemiology of deep venous thrombosis during pregnancy and puerperium in Sudanese women. Vasc Health Risk Manag. 2009;5(1):85-87.

35. James AH, Tapson VF, Goldhaber SZ. Thrombosis during pregnancy and the postpartum period. Am JObstet Gynecol. 2005;193(1):216-219.

36. Ray JG, Chan WS. Deep vein thrombosis during pregnancy and the puerperium: a meta-analysis of the period of risk and the leg of presentation. Obstet Gynecol Surv. 1999;54(4):265-271.

37. James AH. Venous thromboembolism in pregnancy. Arterioscler Thromb Vasc Biol. 2009;29(3):326-331.

38. Galanaud JP, Quenet S, Rivron-Guillot K, et al. Comparison of the clinical history of symptomatic isolated distal deep-vein thrombosis vs. proximal deep vein thrombosis in 11086 patients. J Thromb Haemost. 2009; 7(12):2028-2034.

39. Ginsberg JS, Brill-Edwards P, Burrows RF, et al. Venous thrombosis during pregnancy: leg and trimester of presentation. Thromb Haemost. 1992;67(5):519-520.
40. Satoshi O, Hideo W, Yasunori A, et al. Elevated levels of prothrombin fragment $1+2$ indicate high risk of thrombosis. Clin Appl Thromb Hemost. 2008;14(3):279-285.

41. Rosendaal FR. Venous thrombosis: a multicausal disease. Lancet. 1999;353(9159):1167-1173.

42. Herrmann FH, Koesling M, Schröder W, et al. Prevalence of Factor V Leiden mutation in various populations. Genet Epidemiol. 1997;14(4):403-411.

43. Mathonnet F, Nadifi S, Serazin-Leroy V, Dakouane M, Giudicelli Y. Absence of factor V Leiden mutation and low prothrombin G 20210 A mutation prevalence in a healthy Moroccan population. Thromb Haemost. 2002;88(6):1073-1074.

44. Fall AO, Proulle V, Sall A, et al. Risk factors for thrombosis in an African population. Clin Med Insights Blood Disord. 2014;7:1-6.

45. Engbers MJ, van Hylckama Vlieg A, Rosendaal FR. Venous thrombosis in the elderly: incidence, risk factors and risk groups. JThromb Haemost. 2010;8(10):2105-2112.

\section{Publish your work in this journal}

Vascular Health and Risk Management is an international, peerreviewed journal of therapeutics and risk management, focusing on concise rapid reporting of clinical studies on the processes involved in the maintenance of vascular health; the monitoring, prevention and treatment of vascular disease and its sequelae; and the involvement of metabolic disorders, particularly diabetes. This journal is indexed on PubMed Central and MedLine. The manuscript management system is completely online and includes a very quick and fair peer-review system, which is all easy to use. Visit http://www.dovepress.com/ testimonials.php to read real quotes from published authors. 